\title{
Current Trends in Research in Language Education and Applied Linguistics
}

\section{Jean-Marc Dewaele}

Birkbeck, University of London

I would like to start by thanking the editors of the European Educational Researcher for inviting me to provide the first editorial in their journal. I collaborated with Dr. Nuri Balta (executive editor) and colleagues on a project on the acquisition of Turkish by Kazakh learners. The resulting paper (Dewaele, Özdemir, Karci, Uysal, Özdemir \& Balta, 2019) offered a new language combination in a field where a large majority of papers focus on English as a Foreign Language.

It is notoriously difficult to pick up new trends in language education and applied linguistics. It is a little bit like trying to distinguish a network of footpaths in misty conditions in order to find the one that leads to the mountain top. The view is always incomplete, the ones that seem to be pointing in the right direction might veer off behind the next boulder, and the largest path with most walkers might be interrupted by a landslide, forcing people to scatter and find alternative paths. There is inevitably a belief of researchers that the path they are on is trendy and original. Only years later will this belief be dis/confirmed when a tally can be made through citation indexes of the popularity of that particular path.

Having been active in academia since obtaining my PhD at the Free University of Brussels in 1993, I have had ample opportunity to observe the emergence of new paradigms, of new epistemological stances, of new methods and of the heated debates between the newcomers and defenders of established theories, epistemologies and methods. This continuous evolution is reflected in presentations at international conferences, followed two years later by publications in leading journals. The ability to discern promising new paths of investigation is central to any researcher, especially young $\mathrm{PhD}$ students who are required to produce something original. Going down a well-trodden path will make the discovery of something new and original increasingly harder. The hundreds of researchers who preceded will have more or less exhausted the number of interesting things to say about the path and its views all the way to the end. Finding a new path and pursuing it until some destination is reached requires courage, perseverance and optimism. Well-meaning supervisors and peers might try to dissuade the researcher to step into the unknown. And of course, sometimes they may be right in pointing out that a particular path will be a dead-end. However, just like explorers since dawn of humanity crossed continents and oceans in search of new territories, researchers must set out boldly in new directions, acquiring skills and knowledge that their predecessors did not have, in order to plant their flag on some unclaimed land. The land may however not be so unclaimed after all, and tensions can arise with fellow researchers who may claim precedence and expect subservience. Once the flag is planted, the next step will be to invite other researchers to join and add their own unique perspectives in order to expand the territory in all directions, across disciplinary boundaries. Things can start to go wrong if the early settlers insist on ruling the territory and start expulsing or excommunicating new arrivals that they feel do not respect their authority. Some early settlers may decide to 
move on and create their own independent territory. My own view is that petty disputes harm the reputation of individual researchers and their fields. It is crucial to acknowledge what has been published and to provide impartial reports of relevant previous studies. Nobody "owns" a path or a research area and a welcoming attitude towards newcomers is beneficial for the wider research field.

My own perspective on current trends is inevitably coloured by my efforts to bring emotion into mainstream Second Language Acquisition and Second Language Education research (Dewaele, 2005, 2010; Dewaele \& Pavlenko, 2002). The field was (and in a way still is) heavily dominated by the cognitive perspective. I have no problem with cognitivist approaches, as we need to know, for example, whether corrective feedback from teachers actually helps learners develop their competence in the target language and whether eye-tracking technology can help us shed light on the acquisition of vocabulary in the second language. I do have a problem with cognitivist researchers who act as if only their approach matters and everything else is irrelevant.

The trend that I find most significant in recent years, is the arrival of Positive Psychology in applied linguistics and education psychology (Dewaele, Chen, Padilla, \& Lake, 2019). It brings fresh air in the field, including new perspectives linked to a range of useful theories, concepts and innovative methods. MacIntyre and Gregersen (2012) introduced the Broaden-and-Build Theory of Positive Emotions by American Positive Psychologist Barbara Fredrickson which highlights the effects of positive and negative emotions on thoughtaction repertoires. MacIntyre and Gregersen (2012) adapted the theory to the foreign language education context, arguing that students' positive emotions play a crucial role in overcoming lingering negative emotions. A learner experiencing positive emotions will acclimatize better in the classroom and will be able to absorb more language input while feeling encouraged to participate in the interactions. Inspired by this new approach, Peter MacIntyre and I agreed that researchers had for a long time been overly concerned with negative emotions (anxiety) in Foreign Language (FL) classes and we introduced a new, positive, concept which we labelled Foreign Language Enjoyment (FLE), to complement classroom anxiety (FLCA) (Dewaele \& MacIntyre, 2014). Using an online questionnaire, we collected data from 1,746 FL learners world-wide and found a moderate negative correlation between both emotions, which allowed us to argue that these two dimensions are independent of each other. In other words, lower FLCA does not automatically imply higher FLE. Further research showed that FLE is strongly linked to teacher characteristics and behaviours (Dewaele, et al., 2019; Dewaele, Witney, Saito \& Dewaele, 2018) while FLCA is more related to learner-internal variables such as personality traits and self-related variables (Dewaele \& MacIntyre 2019). The latest learner emotion to draw increasing interest is FL Boredom which can arise from over-challenging or under-challenging activities and can have deleterious effects on learners' motivation and engagement (Li, 2021; Li, Dewaele \& Hu, 2020; Pawlak, Zawodniak \& Kruk, 2020). Recent meta-analyses have shown that learner emotions have a significant effect on learner performance. Botes, Greiff and Dewaele (2020) looked at 67 studies where FLCA had been connected to a FL performance measure and found a moderate negative relationship. Botes, Dewaele and Greiff (2022) carried out a meta-analysis of a total of $\mathrm{k}=97$ effect sizes that linked FLE and various variables. They found that FLE was positively correlated with Willingness to Communicate in the FL, academic achievement in the FL and self-perceived achievement in the FL. This is a clear indication that learner emotions matter in FL education and that teachers who manage to create the optimal emotional atmosphere in their classes will have happier and better-performing students as a result (Dewaele, to appear 2022). I would thus argue that research 
on learner (and teacher) emotions (Gkonou, Dewaele \& King, 2020) is a recent trend that is likely to grow further. What started as a humble footpath may turn into a main thoroughfare in FL education research.

\section{References}

Botes, E., Dewaele, J.-M., \& Greiff, S. (2021). Taking stock: An overview of the literature and a preliminary meta-analysis of Foreign Language Enjoyment and other individual difference variables. Unpublished manuscript. DOI: 10.31234/osf.io/guaj5 Link: https://psyarxiv.com/guaj5

Botes, E., Greiff, S. \& Dewaele, J.-M. (2020) The Foreign Language Classroom Anxiety Scale and Academic Achievement: An Overview of the Prevailing Literature and a Meta-Analysis. The Journal for the Psychology of Language Learning, 2, 26-56.

Dewaele, J.-M. (2005). Investigating the psychological and the emotional dimensions in instructed language learning: Obstacles and possibilities. The Modern Language Journal, 89(3), 367-380.

Dewaele, J.-M. (2010). Emotions in Multiple Languages. Basingstoke: Palgrave Macmillan.

Dewaele, J.-M. (to appear 2022). Enjoyment. In S. Li, P. Hiver \& M. Papi (Eds.), The Routledge Handbook of Second Language Acquisition and Individual Differences. London: Routledge.

Dewaele, J.-M., Chen, X., Padilla, A.M., \& Lake, J. (2019). The flowering of positive psychology in foreign language teaching and acquisition research. Frontiers in Psychology. Language Sciences, 10, 2128. https://doi.org/10.3389/fpsyg.2019.02128

Dewaele, J.-M., \& MacIntyre, P.D. (2014). The two faces of Janus? Anxiety and enjoyment in the foreign language classroom. Studies in Second Language Learning Teaching, 4, 237-274.

Dewaele, J.-M., \& MacIntyre, P.D. (2019). The predictive power of multicultural personality traits, learner and teacher variables on Foreign Language Enjoyment and Anxiety. In M. Sato \& S. Loewen (Eds.), Evidence-based second language pedagogy: A collection of Instructed Second Language Acquisition studies (pp. 263-286). London: Routledge.

Dewaele J.-M., Özdemir C., Karci D., Uysal S., Özdemir E. D., \& Balta N. (2019). How distinctive is the Foreign Language Enjoyment and Foreign Language Classroom Anxiety of Kazakh learners of Turkish? Applied Linguistics Review, https://doi.org/10.1515/applirev-2019-0021

Dewaele, J.-M., \& Pavlenko, A. (2002). Emotion vocabulary in interlanguage. Language Learning 52 (2), $265-$ 324.

Dewaele, J.-M., Witney, J., Saito, K., \& Dewaele, L. (2018). Foreign language enjoyment and anxiety in the FL classroom: The effect of teacher and learner variables. Language Teaching Research, 22(6), 676-697.

Gkonou, C., Dewaele, J.-M., \& King, J. (2020). The Emotional Rollercoaster of Language Teaching. Bristol: Multilingual Matters.

Li, C. (2021). A Control-Value Theory approach to boredom in English classes among university students in China. The Modern Language Journal, 105(1), 317-334. 
4 | DEW AELE

Li, C., Dewaele, J.-M., \& Hu, Y. (2020). Foreign language learning boredom: Conceptualization and measurement. Applied Linguistics Review, https://doi.org/10.1515/applirev-2020-0124

MacIntyre, P.D., \& Gregersen, T. (2012). Emotions that facilitate language learning: The positive broadening power of the imagination. Studies in Second Language Learning and Teaching, 2, 193-213.

Pawlak, M., Zawodniak, J., \& Kruk, M. (2020). Boredom in the foreign language classroom. A microperspective. Cham: Springer. 